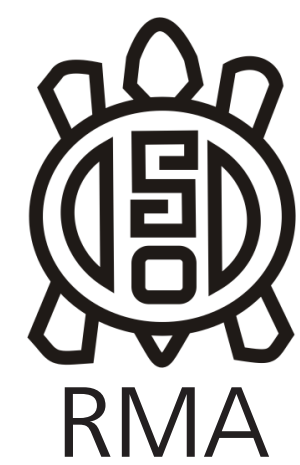

Antropología Social

\section{Líderes y seguidores del Partido Justicialista (P. J.) de Salta durante el recambio de gobierno (2007 a 2011)}

\author{
Leaders and followers of the Justicialista Party (P.J.) of Salta during the \\ government exchange (2007 to 2011)
}

Fernanda Maidana

Instituto Interdisciplinario en Estudios Latinoamericanos (IELA) de la Universidad Federal de Integración Latinoamericana (Foz do Iguaçu, Brasil). E-mail: maidanafernanda@gmail.com

\begin{abstract}
Resumen
Después de tres mandatos consecutivos Juan Carlos Romero deja la gobernación en 2007 y asume Juan Manuel Urtubey, ganador imprevisto de las elecciones de ese año en una coalición electoral por fuera de las filas del P.J. Las rupturas y los realineamientos masivos subsiguientes de seguidores que, además, desatendían la variable partidaria formal, constituían una situación inédita y difícil de entender para muchos electores y observadores. Estos vínculos que parecían inmutables en los doce años de gobierno de Romero y que desafiaban la vulnerabilidad atribuida a las relaciones de poder, finalmente se mostraban frágiles. Propongo analizar la forma en que es puesta en operación una manera de entender el 'hacer política' y el crecimiento político que propicia los realineamientos en el recambio de gobierno, y mostrar que la recomposición posterior parecía seguir los mismos valores, dependencias y coerciones que habían predominado en los años de Romero, permitiendo que los vínculos volvieran a estabilizarse en torno al nuevo gobernador de manera similar.

A lo largo del trabajo analizo situaciones de realineamientos que se producen de forma simultánea al reconocimiento de Urtubey como conductor peronista y al descenso de Romero de su condición de líder provincial, y me detengo en las transformaciones de los partidos, las estrategias electorales y las movilidades interpartidarias que permiten entender que, pese a las continuidades, para las personas de ese universo esos años constituían nuevos tiempos políticos.
\end{abstract}

Palabras clave: Líderes y seguidores; Partido Justicialista; Peronismo; Lealtad; Partidos Políticos.

\begin{abstract}
After three consecutive terms, Juan Carlos Romero leaves the government in 2007 and assumes Juan Manuel Urtubey, unexpected winner of that year's elections in an electoral coalition outside the ranks of P.J. The ruptures and subsequent massive realignments of followers who, in addition, neglected the formal side of the party, constituted an unprecedented and difficult situation to the understanding between many voters and observers. Those bonds that seemed immutable in the twelve years of Romero's government, and that challenged the vulnerability attributed to the power relations, finally proved themselves fragile. I propose to analyze the way in which is put into operation a way of understanding the 'political making' and the political growth that propitiates realignments in the replacement of government. I show that the later recomposition seemed to follow the same values, dependencies and coercions that had prevailed in the Romero years, allowing the bonds stabilize again around the new governor in a similar way.

Throughout the work, I analyze situations of realignments that occurred simultaneously with the recognition of Urtubey as Peronist conductor and Romero's descent of his status as provincial leader. I finish with the transformations in the parties, the electoral strategies and the interparty mobilities that allow the understanding that, despite the continuities, for the people in that universe those years constituted new political times.
\end{abstract}

Keywords: Leaders and followers; Justicialista Party; Peronismo; Loyalty; Political Parties. 
Después de tres mandatos consecutivos Juan Carlos Romero deja la gobernación en 2007 y asume Juan Manuel Urtubey, ganador imprevisto de las elecciones de ese año en una coalición electoral por fuera de las filas del P.J. promovida por funcionarios del Gabinete ${ }^{1}$ del presidente Néstor Kirchner. Tras una atípica, extensa y agotadora campaña, ${ }^{2}$ Walter Wayar, vicegobernador a lo largo de esos doce años y quien sucedería a Romero, pierde como candidato a gobernador del P.J. por una diferencia de votos muy pequeña ante el candidato de la coalición contraria. En un proceso de construcción de liderazgo acelerado, Urtubey había alcanzado gran crecimiento y logrado un triunfo impensado para muchos. Posteriormente las explicaciones de la derrota dentro de las huestes wayaristas referían a la traición dentro del justicialismo, del Intendente capitalino Miguel Isa, de funcionarios romeristas y de intendentes del Interior a Wayar promoviendo el corte de boleta ${ }^{3}$ en la categoría de gobernador; y destacaban una serie de errores groseros en la campaña promovidos por Romero -buscando menguar un triunfo holgado de su vicegobernador- que habían favorecido a Urtubey, como las graves deficiencias en la ingeniería electoral y la falta de un trabajo proselitista riguroso, entre otros.

Para muchos dirigentes se reeditaba la situación de 1991, cuando el P.J. perdía la gobernación ante el Partido Renovador de Salta (P.R.S.), ${ }^{4}$ también por la traición de un sector partidario. Como el P.J. no era gobierno -Urtubey, aunque justicialista había ganado la gobernación en una coalición opositora-, ejercerían el rol de oposición y recuperarían el poder en 2011. Sin embargo, las rupturas y los realineamientos masivos subsiguientes desmentían de forma radical esa posibilidad: en menos de dos años los dirigentes se alineaban al nuevo gobernador y pasaban a considerarlo su líder y conductor, lo que constituía un acontecimiento inédito y difícil de entender para muchos electores y observadores.

\footnotetext{
${ }^{1}$ Utilizo las itálicas para indicar términos nativos y expresiones de los relatos y de las crónicas, comillas dobles para frases textuales y comillas simples para referencias de cientistas sociales y para señalar y relativizar categorías y expresiones propias.

2 A nivel local era observado críticamente por dirigentes de partidos minoritarios, cronistas e intelectuales del medio, la permisividad de la legislación hacia las campañas electorales largas y encubiertas, y la falta casi absoluta de controles sobre los recursos económicos que utilizaban los partidos políticos para financiar sus campañas.

3 La nómina de postulantes a los cargos a elegir, denominada lista, puede ser votada completa o sólo en alguna de sus categorías (gobernador y vicegobernador, diputados, etc.). Esto se conoce como corte de boleta o corte de voto. Es un mecanismo que posibilita elegir candidatos de diferentes listas en los niveles disputados, por ejemplo, el elector puede elegir votar candidato para intendente de una lista mientras que los candidatos a diputados pueden ser los de otra lista y también puede abstenerse de votar en una u otra categoría.

4 Partido provincial que es creado con la reapertura de la democracia por el militar Roberto Ulloa, gobernador nombrado por el presidente de facto durante los años 1978 a 1983 y gobernador electo democráticamente durante los años 1991 a 1995.
}

La desatención de la variable partidaria formal que se producía con los realineamientos en el recambio de gobierno no resulta tan ajena a la comprensión cuando vemos que, como observa Balbi (2010: 2), los estudios muestran que los peronistas sistemáticamente tienden a ignorar las formalidades partidarias, a mantener a sus organizaciones partidarias virtualmente desactivadas por largos periodos de tiempo e incluso, a abandonar sus partidos para realinearse a través de otras formas de organización. Confirmando la similitud con esas conclusiones, es posible observar que para las personas de ese universo llamaba la atención las rupturas de vínculos entre líderes y seguidores y no así la desatención de la variable partidaria.

Estos vínculos que parecían inmutables en los doce años de gobierno de Romero, y que desafiaban la vulnerabilidad atribuida a las relaciones de poder, finalmente, con el nuevo gobernador se mostraban frágiles. Sobre la vulnerabilidad de los lazos políticos, Latour (2008) afirma que las relaciones de poder que no ponen en juego más que capacidades sociales están limitadas a interacciones de corta vida; cuando el ejercicio del poder tiene que depender sólo de vínculos sociales no es posible conservar asimetrías e imponer desigualdades. Por el contrario, su ejercicio duradero se hace efectivo a través de entidades siempre activas y asociaciones que no se descomponen (Latour, 2008: 104/5). ${ }^{5}$

Propongo analizar la forma en que es puesta en operación una manera de entender el 'hacer política' y el crecimiento político que propicia los realineamientos en el recambio de gobierno con el triunfo de un gobernador justicialista y mostrar que, aunque los vínculos entre líderes y seguidores se habían afectado y alterado, la recomposición posterior parecía seguir los mismos valores, entendimientos, dependencias y coerciones permitiendo que éstos volvieran a estabilizarse en una forma similar en torno al nuevo gobernador.

Veremos que este proceso pone en evidencia las condiciones que contribuían a estabilizar esas relaciones, que la durabilidad y la extensión de cualquier interacción es mediada por una particular forma de entender el 'hacer política' y el crecimiento, las necesidades para la carrera y ciertos valores sobre el lazo político de líderes y seguidores y que, junto con los cargos y recursos, conformaban en palabras de Latour- una tecnología para 'construir' jerarquías, asimetrías y desigualdades, medios prácticos para establecer relaciones duraderas y para la dominación.

Simultáneamente a los realineamientos, se produce una modificación de las evaluaciones sobre las aptitudes y cualidades de Urtubey como conductor con capacidad de sustentar el crecimiento político de sí mismo y de sus

\footnotetext{
5 Para Vandenberghe (2006) sería una importante contribución a la sociología esta idea de Latour, de que la integración social es imposible sin objetos que organicen y estabilicen las interacciones humanas.
} 
seguidores. Al respecto, veremos que la conducción y los esfuerzos por controlar la estructura partidaria, fueron temas de preocupaciones y de acciones específicas de los dirigentes del P.J. local. Asimismo, en este período se generalizan ciertas transformaciones en estrategias electorales y movilidades interpartidarias y se cristaliza el debilitamiento de los partidos en su rol de mediación social. Pese a las continuidades evidentes con el período de gobierno anterior, para las personas de ese universo estos cambios señalaban nuevos tiempos políticos.

Con respecto a las fuentes de este trabajo, gran parte la comprende una profusa prensa gráfica sobre temas de la política. ${ }^{6}$ La llamativa cantidad de semanarios que publicaban noticias, notas de análisis políticos, entrevistas, rumores y chismes sobre 'la política' reflejaban la presencia de dirigentes y militantes formados en los '60 y '70 como dueños y colaboradores de estos medios; con vínculos construidos en esa experiencia anterior, incluso de desempeño en los organismos de gobierno, ${ }^{7}$ que alimentaban en encuentros permanentes con ex colegas y nuevas figuras partidarias. Los restantes dueños de semanarios vinculados, fundamentalmente, desde relaciones económicas y/o posiciones críticas independientes u opositoras, reflejaban del mismo modo este fenómeno particular de gran imbricación de la política y la prensa. A pesar de la diversidad de análisis y de interpretaciones que producían, me era posible encontrar un grado de consenso y puntos de coincidencia, dados por códigos similares de interpretación -una 'convergencia de comprensión, conocimientos y valores' (Barth, 2000)- y por cierta información recurrente en situaciones específicas. Estas crónicas me posibilitaban captar los procesos, eventos y situaciones en la dinámica y flujo cotidiano en que se desarrollaban, tanto como una variedad de voces.

Otras fuentes las comprenden la observación de dos meses y medio de la campaña electoral como candidato a gobernador de Walter Wayar en 2011 (acompañando las actividades proselitistas, las reuniones del equipo en las sedes partidarias y los actos públicos), y las entrevistas formales e informales producidas en el flujo de diversos eventos con dirigentes, militantes, legisladores, funcionarios, asesores y trabajadores durante 2010 y 2011. Elegí analizar los datos de estas fuentes desde su observación como discusiones, esto es, como modos públicos de describir, configurar y relatar la acción y

\footnotetext{
${ }^{6}$ Me refiero fundamentalmente a siete publicaciones locales: Nueva Propuesta, El Cronista de Salta, El Expreso, Redacción, Crónica del Noa, Cuarto Poder y El Intransigente. En Maidana (2013) caracterizo los relatos de los registros textuales de esta prensa, sus posibilidades y límites para el análisis. Otros medios gráficos que utilicé fueron El Justicialista, La Cicuta y Propuesta, aunque limitados al tiempo que duraron sus publicaciones y/o según la disposición de ejemplares de colecciones privadas, de la Biblioteca J. Armando Caro y de archivos públicos.

${ }^{7}$ Como era el caso de colaboradores y dueños de las publicaciones El Justicialista, La Cicuta, Nueva Propuesta y El Cronista de Salta.
}

momentos donde las personas realizan operaciones críticas, mientras denuncian, acusan, disputan y justifican (Boltanski y Thévenot, 1991).

A continuación, realizo una descripción que sigue un eje cronológico en la que veremos un proceso continuo de realineamientos y reposicionamientos como seguidores del nuevo gobernador y por el que los dirigentes justicialistas mantenían y recuperaban cargos, espacios y recursos, y se rearticulaban valores, entendimientos, coerciones y dependencias. De forma simultánea, Urtubey pasa a ser reconocido como el nuevo conductor justicialista, con capacidad de sustentar el progreso político suyo y de sus seguidores, controlando la estructura partidaria y logrando triunfos electorales, proyección nacional y el predominio de líderes y dirigentes del P.J. en el ámbito local. Durante este proceso, se producen cambios en las estrategias electorales, en las movilidades interpartidarias y en los partidos.

\section{Los realineamientos y las adhesiones}

En lo que sigue me detengo en dos momentos; primeramente, veremos que se suceden conversiones al urtubeycismo promovidas por el Intendente capitalino Miguel Isa, y el senador provincial Fernando Yarade y, simultáneamente, un acuerdo entre el gobernador y Romero para favorecer la gobernabilidad que orientó apoyos y adhesiones. No obstante, en un segundo momento, los intendentes, legisladores, funcionarios y militantes antes incondicionales a Romero y/o a Wayar que apoyaban obedeciendo al pedido del ex gobernador, deciden reconocer a Urtubey como único conductor en la disputa por el control político de la estructura partidaria, del territorio y en su proyección nacional y brindar soporte a su favor.

A las pocas semanas de su triunfo en 2007, Miguel Isa y su hermano Daniel Isa -un importante operador políticoasí como otros dirigentes hasta entonces wayaristas y romeristas, insistían en la necesidad de tener una relación política con el nuevo gobernador ('hay que arreglar'), y las crónicas referían a que concertaban reuniones. En el caso de los hermanos Isa que habían contribuido de forma subrepticia con votos y apoyo a este candidato, y para quienes era muy grande la dependencia de recursos, obras y convenios del Municipio con la Provincia, esta necesidad se resumía en la frase negociación o muerte.

Durante los años de gobierno de Romero, el monopolio y distribución de cargos, recursos financieros y medios de los organismos gubernamentales eran elementos fundamentales en la dependencia de los dirigentes hacia el gobernador dada la forma de entender el 'hacer política' y el crecimiento político, en la que el acceso a éstos determinaba sus posibilidades de hacer y de crecer en sus carreras. Para el gobernador contar con el apoyo de los intendentes era condición esencial 
para las disputas electorales, como los recursos y obras públicas lo eran para sus gestiones en los municipios. Si bien Romero contaba con un altísimo caudal electoral propio, también dependía de los caudales electorales de intendentes y de diputados y senadores con fuerza territorial, y de su acompañamiento obediente, leal y disciplinado (Maidana, 2010). Aquí vemos que en el caso de los hermanos Isa se expresan de igual modo estos entendimientos y dependencias.

La necesidad y la recreación de una amistad política con el gobernador, propiciaban la generación de una alianza que contribuiría en los meses siguientes a la reconfiguración de las relaciones ya iniciada con el resultado electoral: ambos dirigentes promoverían con éxito el apoyo y la reorientación de lealtades de concejales de la comuna capitalina y de Intendentes del Interior.

Otro acercamiento importante al inicio de su gestión y que sería otra vía por la que se promueve y canaliza la reorientación de vínculos, era el del senador provincial Yarade, ex ministro del Ministerio de Hacienda de Romero visto como un hombre clave en la economía provincial. Aunque considerados muy amigos de la política con experiencias compartidas (como la de haber creado juntos la Escuela de Administración Pública ${ }^{8}$ (EAP) y reclutado de allí una cantidad importante de técnicos para ese Ministerio y las estructuras del gobierno de Romero), era visto como cuadro del romerismo puro y su proximidad justificada como un "nexo y la continuidad en la transición"9, según dichos de un funcionario romerista, -que permitiría "dejar tranquilo al poder económico"10 y optimizar la gobernabilidad-, y vinculada a la gravitación en la política económica del Banco provincial privatizado en el que, según los relatos, Romero tenía una participación societaria y eran administradas las finanzas provinciales y deudas municipales de intendentes desesperados con "coparticipaciones retaceadas". ${ }^{11} \mathrm{Sin}$ embargo, este legislador romerista le había brindado apoyo en su campaña y desde el primer mes de gobierno sería uno de sus primeros seguidores y su principal operador en el Senado, logrando orientar en poco tiempo el apoyo de senadores y pasando a ser considerado -por

\footnotetext{
8 Institución de la sociedad civil creada en 1998 que ofrecía cursos de capacitación a empleados públicos y que desde entonces habría formado a más de 7.500 salteños, según declaraciones de Urtubey (Ver Saltalibre.net, "Fernando Yarade muy cerca de U" por José Acho, 4 de noviembre de 2007). Al asumir el nuevo gobernador en 2007, es transformada en organismo dependiente del Estado para la capacitación y formación de estos empleados.

9 Saltalibre.net, "Fernando Yarade muy cerca de U" por José Acho, 4 de noviembre de 2007

10 Referencia que habría sido utilizada por Urtubey para explicar la proximidad de Yarade a los integrantes de la coalición, según un dirigente de una fuerza partidaria que conforma el Frente electoral en una entrevista que le realizo.

11 Ver www.copenoa.com.ar, "Renegociaciones sigilosas" por Marco Díaz Muñoz, Director Agencia de Noticias Copenoa, 12 de abril de 2008.
}

estas acciones- de absoluta lealtad a Urtubey. Veremos que en las elecciones de 2009 el gobernador promueve su candidatura a la diputación nacional y acompaña su campaña personalmente.

En los dirigentes del P.J. durante los doce años anteriores pude observar que la lealtad era un medio para la autopromoción y el ascenso: siendo leal era posible conseguir y mantener cargos, acceder a espacios y recursos, y disputar posiciones para el crecimiento. Suponía comportamientos de apoyo, de defensa, de renunciamiento, entre otros, que tendían a regular la competencia y la rivalidad y a construir previsibilidad en las relaciones de líderes y seguidores; del mismo modo, los seguidores debían testimoniar lealtad para evitar la coordinación de acciones contrarias de sus pares que, por su vez, así demostraban lealtad al gobernador (Maidana, 2010). Los relatos señalaban que Yarade pasaba a ser considerado de absoluta lealtad de Urtubey y que, por esta condición, un año después era promovido como candidato a un cargo electivo nacional.

A pocas semanas de la nueva gobernación, si bien Romero anunciaba que conduciría la oposición se producían aproximaciones llamativas entre ambos y a partir de entonces el ex mandatario pasaría a orientar apoyos para dar gobernabilidad y Urtubey adoptaría un discurso moderado frente al romerismo. Las crónicas referían a que habían acordado, que el primero temía por acciones de revanchismo y persecuciones ya que los integrantes del Frente electoral ganador buscaban hacer justicia y preparaban denuncias judiciales por distintas decisiones públicas y por sus patrimonios privados; en tanto que el segundo entendía que el líder del P.J. podría valerse de su ascendencia política en las Cámaras y como presidente del partido, y del control de la opinión pública con los medios de comunicación de su propiedad, ${ }^{12}$ para eventualmente llevar adelante oposiciones. ${ }^{13}$ Los dos acordaban y, por este acuerdo, evitarían intromisiones mutuas futuras en los intereses de uno y otro (empresas privadas de uno ${ }^{14}$ y proyectos políticos del otro).

Las designaciones como Jueces en la Corte de Justicia

12 Por el diario local "El Tribuno", por ese entonces el más importante
en tiradas con alcance en toda la provincia, y la AM 840 de la empresa
familiar del gobernador J. C. Romero, Horizontes S.A.
13 Ver El Cronista, 17 de noviembre de 2007, pág.11; El Expreso de
Salta, 14 de noviembre de 2007, "Cambió el escenario de la política"
por EHR, pág. 12; El Expreso, 14 de noviembre de 2007, pág.11. Re-
dacción, 10 de mayo de 2008, "Wayar no viajó", por Jorge Villazón,
pág. 4 .
14 Del Grupo Horizontes de patrimonio familiar y otras de su propie-
dad, según las crónicas, vinculadas a la construcción de viviendas, ins-
tituciones financieras, producción primaria (vitivinícola y de granos),
de industrialización y comercialización de agua mineral, y con la po-
sesión de grandes extensiones de tierra en la provincia. Su padre Ro-
berto Romero, ex gobernador en los años 1983-1987, es señalado en
distintas publicaciones como narcotraficante investigado por la DEA;
sobre J.C. Romero también pesaban sospechas de una relación con el
narcotráfico y era investigado por presunto lavado de dinero en 2007. 
de funcionarios romeristas y los nombramientos de trabajadores en la Administración Central realizados a fines de 2007 que se respetaban en la gestión de Urtubey también eran indicadores de tal acuerdo. ${ }^{15}$ Así como se designaban jueces y trabajadores vinculados con el ex gobernador en un momento previo a su salida que el nuevo gobernador mantenía, gran parte de los técnicos que provenían de la EAP como aquellos funcionarios justicialistas que le habían mostrado adhesión en la campaña o que lo hacían con posterioridad, igualmente retenían sus cargos en el Poder Ejecutivo. ${ }^{16}$

En una provincia históricamente con porcentajes altos de desocupación, donde los trabajadores del sector privado formal constituían aproximadamente el 7\% del total en 2011 y se contaba un empleado público cada 21 habitantes en 2010, ${ }^{17}$ miles de trabajadores y gran parte de los funcionarios dependían de los salarios en cargos públicos. Asimismo, los dirigentes dependían del monopolio de la distribución de cargos por el gobernador -que se extendía a los puestos de trabajo en los niveles medios y bajos de las estructuras de los organismos gubernamentales ${ }^{18}$ - para compensar trabajo proselitista y colocar seguidores (su gente), que trabajarían para orientar acciones en beneficio del proyecto político del dirigente. Por otra parte, los trabajadores podían ser despedidos por no testimoniar adhesión y conformidad políticas (lo que pude observar con trabajadores que colaboraban en la campaña de Wayar, cuando eran advertidos de esa posibilidad). ${ }^{19}$ Vemos que, en la permanencia de esos trabajadores, los cargos en los organismos gubernamentales constituían un medio para el 'hacer política' y el crecimiento político de líderes -y dirigentes- al igual que era entendido en años anteriores.

En tanto que muchos justicialistas, incluso desde antes

\footnotetext{
15 Los Jueces de la Corte de Justicia de Salta eran nombrados por el Poder Ejecutivo con acuerdo de la Cámara de Senadores por el lapso de seis años, pudiendo ser renovados. Sobre las designaciones en los cargos, un cronista relataba que eran cinco mil y todos vinculados a la figura de Romero (El Expreso, 5 de diciembre de 2007, pág.2). Ver Redacción, 8 de diciembre de 2007, pág.4; “Los retrocesos que dividen la sociedad", por J.C.L., pág.17 El Cronista de Salta, 15 de agosto de 2008 .

16 Ver El Cronista, 3 de noviembre de 2007, pág. 27; Redacción, 10 de noviembre de 2007, "Terminó la interna" por Marcelo O'Connor, pág.11; Redacción, 1 de diciembre de 2007, pág.3.

17 Según referencias del INDEC (Instituto Nacional de Estadísticas y (ensos), El Tribuno, 5 de setiembre de 2011

18 Estos cargos eran obtenidos a través de relaciones con dirigentes o mediados por vínculos políticos. Aunque reglamentado el concurso administrativo no era la vía habitual de contratación, con excepción de distintos sistemas de ingreso en Educación, Salud y Seguridad para los que era preciso contar con certificaciones específicas y cumplimentar instancias de selección.

19 En otros momentos históricos y contextos empíricos es posible apreciar la exigencia de adhesión y conformidad como condición para la contratación o mantenimiento de un cargo en organismos gubernamentales. Ver por ejemplo Dormagen (2003) para la Italia fascista y Borges (2006) analizando el empleo en la política en Río de Janeiro (Brasil) en años recientes.
}

de asumir el mandato, se referían a la disputa electoral entre Wayar y Urtubey como una interna resuelta en una elección general (el nuevo gobernador provenía del P.J. y era el mejor producto del romerismo), y a que "debían asumir que estaban ante otra gestión peronista", ${ }^{20}$ los dirigentes de los partidos del Frente ganador cuestionaban y evaluaban negativamente las aproximaciones, las relaciones políticas con dirigentes justicialistas que se retomaban y continuaban, el acuerdo con Romero y la permanencia de funcionarios y trabajadores.

A principios de 2008 el ex presidente se hacía cargo del P.J. a nivel nacional y buscaba, según los relatos, apoyos en distintos puntos del país con el de Urtubey. La dirigencia local lo interpretaba como una decisión de que el gobernador jugara a ese nivel; dado que se especulaba sobre la posibilidad de una vicepresidencia suya en el P.J. nacional ${ }^{21}$ se reevaluaba su gran proximidad a las dos figuras políticas más importantes del momento y pasaba a ser visto como líder con chapa de dirigente nacional.

Daniel Isa en un gesto impensado meses atrás con un todavía poderoso Romero publicaba en la prensa gráfica un pedido de renuncia a este líder a la presidencia del partido -pedido que les costaría el rechazo de un crédito bancario al municipio capitalino ${ }^{22}$. Lo fundamentaba en que había ganado un compañero justicialista, en que el gobernador sabía de las necesidades políticas, en poder participar en el proyecto nacional y en que el P.J. local también debía ser reordenado como lo estaba siendo el P.J. nacional. Para este dirigente y para los concejales justicialistas de la comuna capitalina, se debía conciliar el P.J. con las ideas de Kirchner y de Urtubey, puesto que era una contradicción que el nuevo gobernador participara del Consejo del P.J. nacional y estuviera fuera del P.J. local. ${ }^{23}$

De manera simultánea a los realineamientos y a la rearticulación de lealtades muchos dirigentes señalaban hechos políticos insoslayables, como que el nuevo gobernador había ganado enfrentando a Romero, sin el aparato partidario; con los votos históricamente opositores al justicialismo y logrando centralizar distintas fuerzas políticas partidarias alrededor de su figura -la coalición comprendía una alianza electoral inédita con el P.R.S., y el apoyo de dirigentes de la Unión Cívica Radical (U.C.R.) ${ }^{24}$ tradicionalmente opositores al P.J. y considerados

\footnotetext{
${ }^{20}$ El Expreso, 11 de diciembre de 2007, pág.7.

21 Tiempo después, aunque no obtenía la Vicepresidencia integraba una Junta Promotora en la Secretaría del Interior cuya función era compaginar todo el territorio nacional. Un relato destacaba que el propio Kirchner le había pedido que asumiera esa tarea para acercar posiciones y construir consenso a favor de la nueva conducción nacional (Ver Redacción de fecha 19 de abril de 2008, pág.3).

22 Ver El Cronista de Salta, 15 de marzo de 2008, pág.5.

23 Ver Redacción, 16 de febrero de 2008, pág.7; Redacción, 23 de febrero de 2008, pág.6; Redacción, 3 de mayo de 2008, pág.3.

24 Partido nacional que en la provincia pierde su lugar de segunda
} 
antiperonistas, y el kirchnerista Partido de la Victoria, entre otras fuerzas-; que tenía "mejor conocimiento del contexto" y de "los tiempos políticos" 25 y que se mostraba como figura con proyección nacional.

Al movimiento interno de apoyo "para construir espacios que expresaron las ideas del primer mandatario" según lo definía un cronista, ${ }^{26}$ se sumaba otro que reclamaba el retorno a la participación, al debate y a la legitimación de candidatos con internas democráticas. Como un gesto de oposición a Romero y a su forma verticalista de conducir, participaban y daban apoyo a la visita presidencial para el Acto de Conmemoración de la Revolución de Mayo. Sorprendía a muchos cronistas que esta vez, además, el Presidente de la Cámara de Diputados, Santiago Godoy, hacía declaraciones radiales en el mismo sentido -y uno de ellos observaba que el dirigente "cuestionaba los lineamientos romeristas en una clara muestra de acercamiento a Urtubey", 27 en tanto que coincidían en que esto era necesario si quería, además, ser candidato a diputado nacional y disputar la interna partidaria. Otras crónicas igualmente señalaban estas aspiraciones de promoción del diputado.

El P.J. como partido es caracterizado por la falta de reglas y procedimientos para la selección de dirigentes, por lo que los aspirantes dependen de quienes controlan cargos (Levitsky, 2005). Durante los doce años del anterior mandatario, la nominación en un cargo de jerarquía aparecía viabilizada por el gobernador tanto como las candidaturas a los cargos electivos. Una vez candidato del partido en los primeros lugares de la lista como figura promovida por el gobernador, el dirigente -que debía contar con dinero para la campaña ${ }^{28}$ - podía disputar con éxito, inclusive, sin contar con base electoral. ${ }^{29} \mathrm{La}$ coordinación de acciones de apoyo que viabilizaba el apoyo simbólico de Romero, de dirigentes con stock de recursos políticos y de militantes con la energía social de funcionarios, trabajadores y periodistas, entre otros (que al mismo tiempo mantenían sus posiciones al contribuir a la estrategia de continuidad del líder), aseguraba el éxito electoral. Esa coordinación de acciones colectiva hacía que la campaña estuviera colmada de intervenciones donde se desestimulaba con éxito la competencia de adversarios y opositores, por medio de coerciones diversas como amenazas de quita de beneficios sociales,

$\overline{\text { fuerza con el ascenso del P.R.S. en los ‘90, siendo una agrupación }}$ minoritaria en la actualidad.

25 Ambas referencias eran expresiones reiteradas en dirigentes de la comuna capitalina y, sobre todo, en Daniel Isa.

26 Redacción, 30 de agosto de 2008, pág.4.

27 Ver El Cronista de Salta, 24 de mayo de 2008, pp. 11 y 25.

28 En 2011 era referido que este aporte rondaba los 800 mil dólares.

29 En Maidana (2010) señalo un modelo de crecimiento del 'político desposeído' que es posible reconocer en los años 1995 a 2005, de promoción en los cargos de figuras sin carrera política previa que, al tornarse 'de confianza' del líder y gozar de su apoyo ascendían a puestos electivos sin contar con caudal electoral propio. de contrataciones y de pauta oficial, entre otras.

La nominación en una candidatura a cargo electivo formaba parte de la distribución de oportunidades que realizaba el gobernador, en tanto que las candidaturas que se imponían por fuerza electoral propia debían asimismo ser 'bendecidos' por éste y hasta se adecuaba la regulación electoral para posibilitar ese mayor control. ${ }^{30}$ En el caso de las candidaturas a cargos electivos nacionales esto además obedecía a una lógica de funcionamiento general a las provincias: el proceso de selección de candidatos representaría un mecanismo por el cual los gobernadores controlan los contingentes legislativos de las provincias en el Congreso Nacional que, entre otros, permitirían ejercer influencia en la política nacional (Ardanaz, Leiras y Tommasi, 2012).

Con el conflicto del campo, ${ }^{31}$ en los meses de marzo a junio, se producía una crisis política en la que caía dramáticamente en 16 puntos la imagen positiva de la presidente Cristina Fernández de Kirchner. Asimismo, los gobernadores que la apoyaban perdían imagen, y una consultora que observaba este proceso señalaba que al único que no le ocurría era a Urtubey. ${ }^{32}$ Surgían por entonces movimientos antikirchneristas por la sucesión en los que el gobernador emergía como figura presidenciable. A partir de entonces buscaría capitalizar este reposicionamiento en una apuesta por su proyección nacional ${ }^{33}$ como candidato del poskirchnerismo, con gran publicidad en medios de comunicación nacionales y mediciones constantes de imagen. Al respecto, un año después la tapa de un semanario titulaba: "La proyección nacional de Urtubey es la gran obsesión del peronismo". ${ }^{34}$

En el mes de junio los legisladores que ya adherían al gobernador plasmaban su posición en un documento aval, antes firmado de forma general en el Concejo capitalino municipal. Miguel Isa orientaba además acciones entre los intendentes romeristas del Interior, para "mostrarles que no era Romero o la nada, para que entendieran que Urtubey los contendría si rompían con

\footnotetext{
30 En 2002 se deroga la Ley de lemas (sistema de doble voto acumulativo y simultáneo) implementada en 1990 para mantener la mayoría absoluta del P.J. en las Cámaras, en anticipación a la posibilidad de triunfo del P.R.S. Posteriormente perdía su función y propiciaba el crecimiento autónomo de figuras que no contaban con la confianza del líder y, según entendían dirigentes y cronistas, esto habría constituido la razón principal para su derogación.

31 El conflicto del campo fue así denominado al paro agropecuario y bloqueo de rutas en Argentina de 2008, realizado en los meses de marzo a julio de ese año y en el que las cuatro organizaciones del sector empresario de la producción agro-ganadera protestaron contra la decisión del gobierno de incrementar las retenciones a las exportaciones de soja y girasol y de establecer un sistema móvil para éstas.

32 El Cronista de Salta, 7 de junio de 2008, tapa y pp. 5 y 6.

33 Ver El Cronista de Salta, 1 de agosto de 2008, pág.11.

${ }^{34}$ Ver Redacción, 10 de octubre de 2009.
} 
Romero", según los dichos de un dirigente. ${ }^{35}$

Desde otro movimiento que monitoreaban celosamente los romeristas, se multiplicaban las expresiones de dirigentes de segunda y tercera líneas que pedían su vuelta al partido ${ }^{36}$ y que expresaban públicamente acercamientos para favorecer la gobernabilidad. Asimismo, entendían que debía volver a apoyarse en el P.J. como lo hacía Kirchner, si bien Urtubey afirmaba que su gobierno era peronista, no era pejotista, "debía gobernar con el peronismo", según concluían en una reunión en el partido, ${ }^{37}$ esto significaba reemplazar los funcionarios de otros signos políticos por los cuadros del P.J.

A fines de agosto de 2008 (a nueve meses de asumir) los relatos indicaban que ya casi no quedaba oposición en Diputados. ${ }^{38}$ Santiago Godoy, pasaba a ser considerado por el mandatario un "hombre imprescindible para manejar los hilos del poder legislativo local", según evaluaba un cronista, ${ }^{39}$ y su proximidad justificada por una relación de amistad construida con el tío del gobernador -Julio Mera Figueroa, figura del peronismo local y nacional-, ${ }^{40}$ por viejos pactos del pasado y por una orden de la conducción de volcar su apoyo y acompañamiento a la gestión; como lo hacía también una agrupación de intendentes del Interior que proclamaban su apoyo. ${ }^{41}$ Por entonces, algunos importantes romeristas y urtubeycistas se reunían para revisar "el giro del gobierno hacia la estructura partidaria" y "coincidían en torno de la necesidad de apoyar la gestión provincial y ampliar su base de sustentación política con el aporte del Justicialismo", según declaraban a la prensa. ${ }^{42}$

Del mismo modo, las crónicas señalaban una romerización del Gabinete. Reemplazaba funcionarios de los partidos

\footnotetext{
35 El Cronista de Salta, 8 de agosto de 2008, "Urtubey construye poder" por Jorge Concha Lozano, pág. 11. Sobre estas acciones ver también Redacción, 7 de junio de 2008, pág.3.

36 Renuncia al cargo de consejero del P.J. local en 2007 al salir de las filas partidarias para postularse como candidato del Frente, y se produce su sanción con la suspensión de la ficha de afiliación partidaria (Redacción, 16 de febrero de 2008, "El nuevo bloque justicialista va en busca del control de mandos" por Federico de Alvear; El Cronista de Salta, 1 de marzo de 2008, pág. 17; Nueva Propuesta, 11 de abril de 2008, pp.3 y 4).

37 El Cronista de Salta, 12 de julio de 2008, pág. 4.

38 Ver El Expreso, 18 de junio de 2005, pág.18; El Cronista de Salta, 25 de julio de 2008, pág.7; El Cronista de Salta, 22 de agosto de 2008, pág. 16.

39 El Cronista de Salta, 12 de setiembre de 2008, pág. 6.

40 Dirigente de reconocida militancia en los '80 que se desempeña como asesor de figuras nacionales, en cargos electivos, partidarios y como Ministro del Interior del presidente Menem (cargo al que renuncia en 1991 tras un escándalo por una fallida concesión de la confección del Documento Nacional de Identidad a una empresa francesa para la Aduana Argentina).

41 Ver Redacción, 30 de agosto de 2008, pág. 4; El Cronista de Salta, 12 de setiembre de 2008, pág.6; El Cronista de Salta, 19 de setiembre de 2008, pág. 6; El Cronista de Salta, 26 de setiembre de 2008, pág.5. 42 Ver Redacción, 25 de octubre de 2008, pp.4 y 5.
}

minoritarios del Frente electoral por romeristas. El lema de su campaña -y slogan de su mandato- haciendo realidad el cambio expresaba, entre otros, el objetivo de renovación y superación de la dirigencia romerista que le había permitido captar el voto antiromerista. Esta participación en áreas sensibles de su gobierno era recibida con desencanto por los partidos del Frente, cronistas y electores e indicaba que el P.J. pasaba a ser parte del gobierno.

Hasta aquí vimos que la forma de entender el 'hacer política', desde el acceso a recursos, cargos y por la disponibilidad de medios de esos espacios, era puesta en operación, así como expresaban las mismas dependencias y coerciones del período anterior. Dado que siendo leal era posible conseguir y mantener cargos, acceder a espacios y recursos, y disputar posiciones para el crecimiento, la reorientación de lealtades ante un gobernador salido de las filas del partido resulta una vía 'natural'. Por su vez, veremos en las elecciones de 2009 y 2011 que para Urtubey contar con el apoyo de los intendentes sería fundamental para sus triunfos electorales, al igual que el acompañamiento obediente, leal y disciplinado de diputados y senadores con fuerza territorial y de los restantes dirigentes, tal como lo había sido para Romero durante su gobierno.

\section{Las elecciones de 2009 y el control del partido}

El acuerdo entre Romero y Urtubey comprendía que el problema nacional no fuera transferido al problema provincial, es decir, que las disputas entre líderes nacionales -y las adhesiones locales a esos líderes- no afectaran sus relaciones. Sin embargo, la elección del primer candidato a diputado nacional en 2009 puso a ambos líderes en una situación donde el antikirchnerismo de uno y la incómoda pertenencia al proyecto kirchnerista del otro ${ }^{43}$ producía su enfrentamiento y la finalización de las buenas relaciones.

Daniel Isa se había desempeñado por muchos años como asesor y operador político y en estas elecciones promovía su candidatura a la diputación nacional a partir de la alianza con el gobernador, de la proximidad que construía como ultrakirchnerista con el presidente Kirchner (que retrataba en fotos), del apoyo de concejales, del Intendente del municipio capitalino -su hermano Miguel Isa-, y de algunos dirigentes del Interior de la provincia. Para Romero, esta candidatura constituía una provocación a su oposición al kirchnerismo y pertenencia al Peronismo disidente y, por esto mismo, un obstáculo a su interés de encolumnar el P.J. local a esa línea nacional. Resolvía apoyar a Wayar, figura que había expresado su antikirchnerismo en distintos momentos y cuya fuerza política partidaria podía desbancar la postulación del primero. Aunque el gobernador construía independencia

\footnotetext{
${ }^{43}$ Ver Nueva Propuesta, 20 de marzo de 2009, pág.9; Nueva Propuesta, 27 de marzo de 2009, pp. 2 y 3.
} 
y expresaba críticas y oposición a algunas medidas nacionales, no buscaba mostrarse enfrentado y no aprobaría un candidato opositor al gobierno nacional.

A fines de marzo de 2009 se oficializa la creación del Fondo Federal Solidario por el que se distribuía a las provincias que adherían y a sus municipios el 30\% de lo recaudado en concepto de retenciones a la soja destinado a obras públicas. El gobernador por entonces sumaba a esa distribución un porcentaje mayor para los municipios: coparticipaba a los municipios el 20\% más de lo previsto por la ley de coparticipación y de los fondos provenientes de las retenciones a las exportaciones. Esta cifra representaba en 2010 un 35\% de lo que la provincia les coparticipaba según el presupuesto; ${ }^{44}$ y en ese año además, descentralizaba fondos sociales, aproximadamente unos 125 millones de dólares ${ }^{45}$ que se destinarían a los intendentes. Un ex intendente capitalino me explicaba en una entrevista: por eso todos los intendentes se hicieron urtubeycistas de un día para otro. El efecto de esta medida en los realineamientos se evidenciaría en las semanas siguientes.

A través del Consejo Partidario, el ex gobernador desistía de la lista unificada y abría la posibilidad al mecanismo de colectoras. Por entonces, mientras muchos dirigentes expresaban apoyar al gobernador como nuevo líder del peronismo, otros se veían obligados a posicionarse. ${ }^{46}$ En esta dirección, manifestaban que Romero tomaba decisiones que "no estaban dispuestos a acompañar" (de poner al peronismo salteño al servicio del Peronismo disidente y en contra de Kirchner), "como tampoco en condiciones de arriesgar la ayuda social y las obras que recibian de la presidente". ${ }^{47}$

A fines de abril más de 300 dirigentes con cargos legislativos, provinciales y municipales se reunían a discutir con Urtubey, y 99 de los 119 congresales del partido solicitaban la convocatoria urgente a Congreso Partidario. ${ }^{48}$ Un cronista señalaba que esta

\footnotetext{
44 Cuarto Poder, 9 de julio de 2011, "Los proctólogos" por Daniel Avalos, Contratapa.

45 Ver Redacción, 20 de junio de 2009, pág.8; Semanario Redacción 24 de abril de 2010, pág. 8.

46 Ver El Expreso, 22 de abril de 2009, "Las dos caras del peronismo" por O.B, pág.5; El Expreso, 29 de abril de 2009, "Romero con un pie afuera" por O.B., pág.4; El Expreso, 29 de junio de 2009, pág. 8.

${ }^{47}$ El Expreso, 29 de abril de 2009, pág.4.

48 Hasta el año 2004 la fecha de la elección presidencial era fijada por el Poder Ejecutivo Nacional y la de los comicios legislativos la determinaba el gobierno de cada provincia. En diciembre de ese año se sanciona la ley 25.983 que unifica la realización de todos los actos electivos de cargos nacionales en el cuarto domingo de octubre; en ese año, además, se aprueba el adelantamiento de las elecciones nacionales, lo que afecta el cronograma electoral provincial y obliga a definir los candidatos por Congreso Partidario en una lista única y no por elecciones internas partidarias. Por otra parte, 2009 es el último año en que los candidatos a cargos electivos nacionales podían elegirse por Congreso Partidario y en ese año podían optar incluso por Internas Abiertas y Simultáneas. En 2008 un proyecto del Ejecutivo provincial aprobado por las Cámaras introduce el voto electrónico,
}

autoconvocatoria era un punto de inflexión en la disputa entre ambos líderes: "inauguraba un nuevo período en el que más de una década de hegemonía y mandato indiscutible de Romero se empezaba a desmoronar". ${ }^{49} \mathrm{La}$ disputa por las candidaturas que el Congreso Partidario aprobaría a fines de abril ahora comprendía el control territorial del peronismo y el manejo del P.J. Era entendido que estaba en juego la reelección en la gobernación y que necesitaba la estructura del P.J. para ser presidenciable. ${ }^{50}$

Romero acabaría promoviendo al ex vicegobernador en un Frente opositor al P.J. que apoyaba al Peronismo disidente, Daniel Isa renunciaba a su postulación y el Congreso aprobaba la candidatura del senador Yarade, el dirigente considerado de absoluta lealtad del gobernador. Wayar decidía postularse por fuera de las filas del P.J. tras evaluar por largo tiempo el impacto que esto tendría en su imagen de peronista auténtico y ser alentado por la constatación que surgía a partir de Urtubey (y a nivel nacional, con Kirchner), señalada por dirigentes y analistas de la prensa, de que "por ser candidato de otro Frente, no dejás de ser [considerado] peronista"; "Si Urtubey lo hizo y volvió como si nada, por qué no podés hacerlo vos que sos más peronista que cualquiera". ${ }^{51}$

Pocos días después Daniel Isa publicaba un nuevo pedido de renuncia a Romero como presidente del P.J., mientras dirigentes de segunda línea lo acusaban de traidor por falta de conducta política hacia el partido ${ }^{52}$ señalando "una situación inédita": que el presidente del partido no apoyara a los candidatos del mismo partido y que pidiera no votar por el P.J. ${ }^{53}$

En las elecciones generales para renovar tres bancas legislativas nacionales a fines de junio, los partidos del Frente electoral conformado en 2007 disputaban de forma separada. Era observado que el voto se había ido a la derecha y que los sectores altos identificados con el rechazo al kirchnerismo apoyaban a Wayar como candidato del Peronismo federal, lo que acaba expresándose en puntos de ventaja en Capital. Si bien en el Interior resultaba ganador Yarade en 21 de los

paulatinamente implementado desde 2009. A partir de 2011 se aplica el sistema de elección de Primarias, Abiertas, Simultáneas y Obligatorias (PASO) y la modalidad de las colectoras, de acuerdo a las reformas nacionales al sistema electoral producidas en 2009.

49 Ver El Cronista de Salta, "La vocación de poder del Peronismo es el Motor de la Interna" por RRCH, 13 de junio de 2009, pág.3.

50 Ver Redacción, 18 de abril de 2009, pág.3; El Expreso, 22 de abril de 2009, pág.7; El Expreso, 22 de julio de 2009, pág.6.

51 El Expreso, 29 de octubre de 2008, “¿Si Urtubey lo hizo por qué yo no?", pág.2

52 Ver Redacción, 23 de mayo de 2009, págs. 2 y 4; El Expreso, 10 de junio de 2009, pág.6. Boivin, Rosato y Balbi (2003) distinguen dos formas de traición que observan en dirigentes peronistas de una localidad de Entre Ríos: la traición contra el líder político cuando tiene por referencia las relaciones personalizadas entre individuos, y la traición contra el partido, cuando se violentan de alguna forma la inscripción pública de un individuo en las referencias simbólicas del colectivo social partidario.

53 El Expreso, 10 de junio de 2009, pág.6. 
23 departamentos y se imponía con $29,36 \%$ de los votos totales, el P.J. perdía una banca de las dos que históricamente conseguía por la buena elección que hacían Wayar $(23,50 \%)$ y un productor sojero $(17,05 \%)$, candidatos de los Frentes apoyados por Romero.

Asimismo, eran observados cambios relevantes en la lealtad del voto, las estrategias electorales, las movilidades interpartidarias, la competencia política, las divisiones y fragmentaciones partidarias y la reconfiguración de la oposición. Con sorpresa cronistas, dirigentes, analistas y cronistas señalaban que votantes tradicionales del P.R.S. se habían inclinado por Yarade -y no por el candidato de su partido y que, incluso, intendentes renovadores habían apoyado su campaña; del mismo modo, militantes y dirigentes barriales justicialistas habían votado por Wayar y no por el candidato de su partido. Para analistas de consultoras que eran entrevistados por los medios y observadores -cronistas y dirigentes-, se evidenciaba "poca estructura de voto leal al partido"54 y los resultados electorales demostraban "que los votos del sello del P.J. no tenían peso electoral". ${ }^{55}$ Además, era señalada la multiplicación de candidatos en frentes y alianzas, la fuerte fragmentación y división de los partidos y la gran movilidad interpartidaria: "Ios que estaban adentro en 2007 [ahora] están afuera, y los que estaban afuera [ahora] están adentro","56 los que eran oficialistas se habían dividido en oficialistas y opositores; los que eran romeristas habían pasado a ser urtubeycistas y seguidores de Isa, y se podían encontrar desperdigados en distintos Frentes al igual que a dirigentes del P.R.S. y de la U.C.R. ${ }^{57}$ A propósito de esa movilidad, era observado que había provocado desconcierto en los electores justicialistas puesto que en estas elecciones se les pedía votar en contra de Wayar, cuando en 2007 se les había pedido votar a favor. $^{58}$

Los dirigentes entendían que el P.J. ya no alcanzaba el 35\% histórico y menos aún dividido; uno de ellos señalaba que había pasado a contar con un $25 \%$ de votos (mientras que el otro 25\% era antiperonista y el $50 \%$ restante correspondía a votantes independientes). ${ }^{59}$ En esa dirección, los seguidores más próximos al gobernador y quienes transmitían su pensamiento, promovían que en las elecciones siguientes de 2011 los partidos volvieran a conformar la coalición electoral formada en 2007, en la que el P.J. fuera el eje central. No obstante, el efecto de apertura de la competencia que producía la alianza y las políticas de descentralización de recursos y obras

\footnotetext{
54 El Expreso, 24 de junio de 2009, pág.6.

55 El Cronista de Salta, 10 de julio de 2009, "Los compañeros ya no se reproducen, ahora se divorcian" por $\mathrm{RRCH}$, pág. 2 .

56 Nueva Propuesta, 15 de mayo de 2009, "Parece que ir por afuera es la clave" por Daniel Salmoral, pág. 5.

57 El Expreso, 14 de setiembre de 2009, "A la hora del desencanto" O.B., pág. 3.

58 El Expreso, 29 de junio de 2009, p.2.

59 El Expreso, 20 de abril de 2011, pág.7.
}

que contemplaba a intendentes de otros signos políticos, alteraba las reglas de juego al generar adversarios en estas fuerzas ahora en mejores condiciones de disputar que, además, contaban con apoyo del gobernador. De tal modo, los dirigentes criticaban que les "paraban candidatos en el territorio"60 $\mathrm{y}$, posteriormente, que la realización de internas partidarias en el P.J. con la implementación simultánea del sistema de colectoras en 2011 beneficiaba igualmente a extrapartidarios (cuyos partidos no sufrían internas desgastantes y divisoras, ni enconos que se canalizaban en apoyos a frentes o figuras extrapartidarias).

A partir de los resultados de esta elección y del temor de que le proveyeran soporte político para renovar su presidencia en el P.J., se sucedería un fuerte operativo para conseguir desplazar a Romero. El Congreso Peronista asumía el control político, creaba la Comisión de Acción Política -que modifica la Carta Orgánica-, vaciaba de facultades a su Consejo y renovaba las autoridades para los Congresos Provincial y Nacional. ${ }^{61}$ Posteriormente el conflicto se judicializaba, con la amenaza de intervención del partido. Si bien Romero continuaría en la presidencia hasta fines de 2010, sus decisiones ya no tenían respaldo político. ${ }^{62}$

En las elecciones de cargos electivos locales (legislativos y municipales) que se realizan en setiembre de ese año, aunque los dos frentes que Romero apoya obtenían un 23,37\% (Frente Salteño) y un 6,91\% (Frente Federal), el P.J. alcanzaba el $24,14 \%$ y los análisis referían a la contundencia del voto oficialista en el Interior. En consonancia con este triunfo, en el mes de octubre un semanario reproducía como título de tapa los dichos de un funcionario urtubeycista (antes wayarista) al respecto del gobernador y los dirigentes justicialistas: "Romero ya fue, la nueva realidad peronista pasa por Urtubey". ${ }^{63}$

El gobernador había pasado a ser reconocido como el único conductor del peronismo local. Balbi (2010) señala que los peronistas atribuyen a la capacidad de conducir la potencialidad de crear realidades políticas, de dar forma al propio peronismo y de generar su predominio en la escena política y valoran esta capacidad por sobre cualquier otra; y es considerado conductor el líder que es capaz de producir hechos políticos, ganar elecciones, abrir espacios formales e informales para el accionar

\footnotetext{
60 Nueva Propuesta, 11 de diciembre de 2009, pág.6.

${ }^{61}$ Ver El Cronista de Salta, 3 de julio de 2009, pág. 3; Nueva Propuesta, 3 de julio de 2009, pág. 8; El Cronista de Salta, 10 de julio de 2009, "Los compañeros ya no se reproducen, ahora se divorcian" por RRCH, pág.9; Redacción, 26 de julio de 2009, pág.4; El Cronista de Salta, 31 de julio de 2009, tapa.

62 Cuando Romero renuncia a la presidencia del P.J. y a su ficha de afiliación en 2010 para participar como candidato de otros partidos, la fecha de su presentación obligaba a realizar su tratamiento recién en la primera reunión del Congreso Partidario en 2011 por lo que la asunción de Urtubey será recién en ese año (El Intransigente, 9 al 15 de diciembre de 2010, pág. 6; Redacción, 18 de diciembre de 2010, pág.3).

63 Redacción, 10 de octubre de 2009, pág. 4.
} 
político de sus seguidores y proporcionar el acceso a cargos y recursos e ingresos, entre otros. Por su vez, desde la óptica del conductor peronista, debe haber unidad de concepción, disciplina y encuadramiento en la organización (Balbi, 2010).

Por entonces, el mandatario pedía más gestos de respaldo a su gobierno y que la tropa se disciplinara en función de los resultados electorales, que todos los legisladores e intendentes se sumaran a la gestión. Diputados e intendentes evitaban encontrarse con el ex gobernador, incluso en eventos informales como festejos de cumpleaños, para mostrarse distante también físicamente, y declaraban públicamente lealtad al gobernador ${ }^{64}$ con expresiones de agradecimiento por la apertura, la atención, el apoyo para obras que en la gestión de Romero no lo habían tenido, destacando un mayor protagonismo, responsabilidad y alcance de sus políticas.

\section{Elecciones de 2011}

Para las elecciones a gobernador de 2011 Urtubey aspiraba a la relección en un Frente que incorporaba la mayor parte de las alianzas de 2007, al que se sumaba el P.J. ${ }^{65}$ y el apoyo de siete colectoras. ${ }^{66}$ El ex gobernador desistía de su candidatura al resultar acorralado por denuncias judiciales que lo involucraban seriamente en un resonado caso de corrupción destapado para frenar sus ansias reeleccionistas; ${ }^{67}$ y se sumaba desalentándolo el debilitamiento del Peronismo disidente.

Algunas observaciones de los cronistas y de romeristas referían críticamente a que la obediencia de los dirigentes hasta permitía que el P.J. se lanzara dentro de un frente electoral 'inaudito' desde la misma denominación: Frente

\footnotetext{
64 El Cronista de Salta, 9 de octubre de 2009, pp. 3 y 11; El Expreso, 4 de noviembre de 2009, pág.6; Nueva Propuesta, 1 de octubre de 2010, pp. 12 y 3.

65 Los partidos P.R.S., Partido de la Victoria, Unión Victoria Popular, Frente Grande, Memoria y Movilización y Movimiento Popular Unido.

66 Con las reformas políticas de 2009 también es implementado el Sistemas de colectoras que consistía en listas de 'adhesión', en las que un individuo es candidato de varios partidos a la vez. Un conjunto de listas de diversos partidos puede presentar candidatos propios para una cierta categoría (por ejemplo, diputados) pero adherir a una misma lista de candidatos para otras categorías (por ejemplo, presidente), sin presentar candidatos propios. Al respecto, un dirigente salteño destacaba que con este sistema en la provincia de Tucumán el gobernador resultaba candidato de más de 40 partidos en 2011.

67 El Caso de las Tierras de la Ciénaga, tal como se denominó en los medios, implicaba al ex mandatario en denuncias por enriquecimiento ilícito (y posteriormente, en las causas de apoderamiento de tierras del Estado y de utilización con fines de lucro de informaciones o datos de carácter reservado, en la que también resultaba implicado un ex ministro de su gestión). Comprendía unas tierras que se habían comprado en su gobierno a un precio sumamente alto que, tras pasarla por dos compradores, quedaban en una empresa de su familia y a un precio bajísimo respecto al pago inicial (Ver Cuarto Poder, 10 de setiembre de 2011, pág. 3; Crónica del NOA, 8 al 15 de octubre de 2011, pág.6; El Expreso 6 de octubre de 2011, pág.8; Nueva Propuesta, 8 de octubre de 2010, pág. 4).
}

Justicialista Renovador para la Victoria; la unión de siglas del P.J. con las del P.R.S. resultaba una contradicción ideológica dado que Justicialista y Renovador eran términos tenidos como incompatibles según el origen conservador, antipopular y de derecha del segundo. El Frente proponía la reelección del vicegobernador electo en 2007, figura de ese partido, y del mismo modo promovía a intendentes de otros signos políticos. Este fenómeno resultaba inconcebible para algunos dirigentes y producía mucho rechazo en militantes del P.J. que cuestionaban el apoyo a listas con renovadores. Para estos últimos, además de la dificultad que ya representaban las nóminas con candidatos desconocidos en el Interior, con "ninguna obra que mostrar" y como único mérito la lealtad al gobernador, se les sumaban estos postulantes antipopulares: "¿cómo hacer para convencer a la gente de votar a esta lista, que encima tiene a una renovadora de lo más recalcitrante?". 68

Era destacado que los informes de las consultoras indicaban que se producía en el electorado la asociación de la gestión del gobernador con la presidente, y dada su alta imagen por entonces, eso se reflejaba en las mediciones. ${ }^{69}$ Sin embargo, y desde la distancia política con este gobernador, el Ministro de Planificación, Inversión Pública y Servicios del Gabinete presidencial, Julio de Vido, con un importante gremialista nacional, Hugo Moyano, promovían la candidatura a gobernador de Wayar, quien había acordado previamente una 'convivencia política' como diputado nacional favorable con el kirchnerismo. En la campaña de este ex vicegobernador, que pude observar y acompañar personalmente, eran desanimados de participar y colaborar empresarios, trabajadores y medios de comunicación por amenazas de despido, quita de publicidad y contrataciones, etc. por funcionarios de organismos gubernamentales urtubeycistas. Vemos aquí otra similitud con la gestión de Romero, en la que la mayoría de los medios de comunicación dependía de los ingresos por publicidad oficial (que eran distribuidos en la construcción de una visión positiva de la gestión y del líder) y, al igual que empresarios y trabajadores, podían perder sus contrataciones si apoyaban adversarios.

En estas elecciones el gobernador había expandido aún más su influencia a dirigentes de la U.C.R., la otra fuerza tradicionalmente tenida como opositora del P.J. en la provincia. En sus discursos se refería con frecuencia a que era candidato de un Frente, no del justicialismo y, luego de su triunfo, un cronista observaba que en sus declaraciones "minimizaba la importancia de los partidos políticos"y, a propósito de esto, agregaba: "Los partidos no importan, importa Urtubey". ${ }^{70}$

\footnotetext{
68 El Expreso, 6 de julio de 2011, pág.5.

${ }^{69}$ Ver Redacción, 8 de abril de 2011, pág.6; Crónica del Noa, 5 al 14 de abril de 2011, pág.3.

${ }^{70}$ Ver El Cronista, 8 de abril de 2011, pág.20.
} 
Legisladores e intendentes del P.J. declaraban por entonces que el gobernador representaba una nueva esperanza para el peronismo y que apoyaban su reelección. ${ }^{71}$ Por otra parte, un cronista evaluaba que "la estrategia electoral había logrado instalar la sensación en la población de que, con independencia de los esfuerzos de candidatos opositores, el resultado electoral le sería ampliamente favorable", que los dirigentes justicialistas se habían disciplinado a su liderazgo y que "la vieja práctica justicialista se reeditaba": "la de lograr que las rencillas en el seno del P.J. fueran protagonizadas por segundas líneas dispuestas a representar mejor la ortodoxia oficial". ${ }^{72}$ Es decir, que compitieran entre sí por ser y/o parecer el mejor urtubeycista de todos (el más leal y por eso merecedor de oportunidades políticas), y no que rivalizaran con el líder disputando su autoridad.

Aunque el P.J. perdía intendencias y crecía un partido minoritario opositor, el Partido Conservador Popular, el Frente obtenía la tercera colocación con un 8,47\% de los votos y Urtubey la primera con el 58\%. La alianza con distintos sectores y partidos le había permitido ganar con ese alto porcentaje, según refería un dirigente urtubeycista. ${ }^{73}$ A propósito de este importante apoyo, Romero criticaba en sus declaraciones a los medios "que todos los partidos fueran tributarios y obsecuentes a un gobernador" y que, al hacer esto, "perdieran su identidad partidaria".

Para el analista de una consultora, había tenido "un gran acompañamiento del Interior, gracias a las obras públicas y la ayuda social;"74 del mismo modo un cronista observaba éste había sido nuevamente "el baluarte electoral del urtubeycismo" y que sus políticas ayudaban a mantener "el poder territorial de los Intendentes que, en su mayoría, habían conseguido ser reelectos". ${ }^{75}$ Un senador se refería también a que "el peronismo aperturista de Urtubey le había dado una posibilidad histórica al Interior: Antes se centralizaba más en Capital, hoy tenemos en nuestro departamento siete $u$ ocho obras en ejecución"; 76 y un Intendente, presidente del Foro de Intendentes de la provincia y electo por sexta vez consecutiva, declaraba en los medios que les "había dado a todos los intendentes sin importar los partidos políticos."77

\footnotetext{
71 Ver El Expreso, 25 de agosto de 2010, pág.3; Nueva Propuesta, 3 de setiembre de 2010, pág. 4 y 5; Ver Nueva Propuesta, 1 de octubre de 2010, pág. 12/3; Ver Semanario Redacción 24 de abril de 2010, pág. 8.

72 Ver Cuarto Poder, 2 de abril de 2010, pág. 11.

73 El Expreso, 20 de abril de 2011, pág.7.

74 El Expreso, 13 de abril de 2011, pág. 6.

75 Cuarto Poder, 9 de julio de 2011, “Los proctólogos" por Daniel Avalos, Contratapa.

76 El Expreso, 11 de mayo de 2011, pág. 11.

77 Redacción, 7 de mayo de 2011, Contratapa.
}

Por otra parte, se trataba de las primeras elecciones generales en las que se ampliaba la implementación del voto electrónico, de treinta y seis mesas de dos localidades en 2009 a setecientas veinticinco mesas en siete localidades; ${ }^{78}$ el $33 \%$ del padrón votaba con voto electrónico. ${ }^{79}$ Los dirigentes de la oposición denunciaban fallas electrónicas, falta de transparencia en el proceso y fraude electrónico. Aunque provocaba mayor ausentismo electoral por el miedo a la máquina, para el analista de una consultora "había posibilitado mayores cortes de la boleta y abandonar la lista sabana, por lo que reflejaba mejor que la gente empezaba a votar a la persona y no tanto a partidos". ${ }^{80}$

En abril de 2011 el gobernador asumía la presidencia del P.J. y los relatos destacaban su discurso de asunción, que lo realizaba "con los símbolos históricos del peronismo", con un auditorio militante y "los infaltables bombos $y$ la marcha". ${ }^{81}$

En las elecciones generales siguientes de octubre de ese año, en las que se produce la re-elección de la presidente Cistina Fernández de Kirchner, los resultados de los candidatos que apoyaba Romero eran muy bajos (50 mil) y representaban el $8 \%$ del total de votos, mientras que los medios publicaban que su imagen negativa llegaba al 67 por ciento. ${ }^{82}$

Para los observadores, tras esta última elección el gobernador repetía el éxito de las elecciones anteriores. Conseguía revalidar su liderazgo con sucesivos triunfos electorales y mantener el predominio justicialista en el ámbito público-político. Desde la reapertura de la democracia en 1983, éste se había expresado en una abrumadora mayoría en las Cámaras y en las Intendencias y en 2011 muchos de sus dirigentes contaban con más de dos décadas en cargos electivos o políticos que podían seguir conservando.

\section{Reflexiones finales}

Balbi (2007) bien observa que en Argentina la política es frecuentemente representada, especialmente en los medios de comunicación, como una actividad carente

\footnotetext{
78 Salta Capital, San Ramón de la Nueva Orán, San Lorenzo, San José de Metán, Cafayate y La Caldera.

79 Este sistema consistía en una máquina de votar (no en una urna electrónica), en la que la computadora no cuenta con disco interno de registro de votos, sino que los imprime en boletas individuales que son colocadas por el elector dentro de una urna y, posteriormente, una vez cerrado el acto eleccionario, éstas se escanean para el recuento.

${ }^{80}$ Ver El Expreso, 13 de abril de 2011, pág. 6 Gustavo Acuña/ Consultora ICQ "Hubo errores groseros de la oposición".

${ }^{81}$ Ver Nueva Propuesta, 21 de abril de 2011, pág. 8.

82 Ver Nueva Propuesta, 28 de octubre de 2011, pág.4; Redacción, 29 de octubre de 2011, pág. 2; Redacción, 5 de noviembre de 2011 pág.4.
} 
de valores $^{83}$ y que las apelaciones de los políticos a expresiones de carácter moralizante son objeto de comentarios irónicos por periodistas u otras figuras de los medios. Del mismo modo, en el estudio del peronismo diversas modalidades de acción que se reiteran en el comportamiento de los peronistas habrían sido tratadas como meros productos del pragmatismo y el oportunismo. En el caso de Salta pude observar una perspectiva en la prensa gráfica que privilegia los cálculos estratégicos y el pragmatismo, y en la que la apelación a registros normativos y axiológicos era entendida como falsa retórica (Maidana, 2013). Por el contrario, Balbi (2010) observa el peso de concepciones y prácticas estructuradas por valores y de una forma específicamente peronista de entender 'la política' y de hacerla al considerar las concepciones sobre el conductor y la conducción y las actitudes respecto a las estructuras partidarias formales (como los esfuerzos para controlarlas); y muestra etnográficamente que la lealtad es un valor moral ${ }^{84}$ que configura las formas de confianza, expectativas y percepciones y un medio del comportamiento, desplegado a fines de posicionarse y de disputar entre sí (Balbi, 2007). Pude observar, asimismo, que este valor participaba en la regulación del crecimiento político en los dirigentes del P.J. de Salta durante el gobierno de Romero, 1995-2007; en esos doce años las aspiraciones y proyectos de crecimiento político de estos dirigentes eran articulados y llevados adelante en términos de la lealtad prodigada al gobernador, puesto que dar pruebas de ella era un medio para la autopromoción y el ascenso (Maidana, 2010).

A lo largo de este trabajo busqué mostrar que la forma de entender el 'hacer política' y el crecimiento propició la alteración de lealtades a partir del triunfo de Urtubey. El acceso a cargos, recursos y medios de esos espacios seguía siendo entendido como un factor determinante para hacer política, llevar adelante una carrera y crecer políticamente. Del mismo modo, el monopolio de su distribución continuaría reproduciendo la dependencia de los dirigentes hacia el gobernador y, por su vez, la de éste con los dirigentes con fuerza territorial. Dado que siendo leal y obediente se accedía y se mantenían cargos, espacios y recursos y que Urtubey mantenía y actualizaba relaciones políticas con muchos justicialistas y con Romero, la reorientación de lealtades surge como posibilidad inmediata.

Para los dirigentes este líder conseguía mejores alianzas, lograba centralizar distintas fuerzas partidarias en torno a su liderazgo, tenía un mejor conocimiento del contexto,

\footnotetext{
83 Pese a la publicidad que alcanza esta visión crítica, restrictiva e irónica sobre la política, ésta no sería producida desde los medios de comunicación sino por los mismos electores. Gaxie (2003) relativiza la fuerza de los medios a partir de su investigación con votantes franceses, señalando su lugar secundario para construir esa visión por sí mismos.

84 Distintos contextos empíricos de sucesivas etnografías indican formas similares y recurrentes en las concepciones y prácticas de los peronistas (Balbi, 2007; Frederic y Soprano, 2008).
}

era más horizontal, ofrecía más participación, daba más recursos a los intendentes y cedía cargos y espacios; del mismo modo, sus triunfos electorales, su proyección a nivel nacional y mantener el predominio de líderes y dirigentes del P.J. en el ámbito local, lo hacían un mejor conductor que Romero. Disponía las reglas electorales (plazos, reformas, etc.), del aparato partidario, del poder institucional del gobierno y de seguidores en esos ámbitos que articulaban y coordinaban acciones en contra de sus adversarios -y a favor de los propios y de aliados extrapartidarios- por medios coercitivos (el riesgo de perder contrataciones, empleo, etc.). En tanto que el liderazgo de Urtubey crecía, el ex gobernador Romero perdía su ya reducido protagonismo y posicionamiento en el ámbito nacional, su poder territorial y su base electoral, y había dejado de tener control sobre recursos, espacios y cargos.

Vimos que la autoridad de Urtubey como conductor se articulaba con la administración de dependencias y coerciones desde entendimientos y valores compartidos sobre la forma de 'hacer política' y los vínculos entre líder y seguidores, que conseguía gestionar eficazmente. Los dirigentes, por su parte, testimoniaban lealtad $y$ obediencia como seguidores; sus reposicionamientos y realineamientos eran acompañados de muestras y declaraciones de adhesión y apoyo político, de defensa y de disciplina. La recomposición de estas relaciones había mantenido similares características a aquellas que predominaron durante los doce años de Romero.

A partir de 2007 se generalizaban cambios en las estrategias electorales y en la dinámica política local. Pese a las continuidades en la rearticulación de los vínculos entre líderes y seguidores y en el predominio del peronismo, eran observadas transformaciones en los partidos que, para las personas de ese universo, marcan otros tiempos políticos.

Son diversas las transformaciones translocales que afectaron a los partidos en América Latina y el mundo desde los '80 y '90, como la dilución de las identidades partidarias, la pérdida de lealtad del electorado a estas identidades y los nuevos tipos de vínculos representativos a partir de la personalización de la política (Manin, 1995; Pitkin, 2006; Cavarozzi y Casullo, 2002; Novaro, 1994; Pousadela, 2004; Sidicaro, 2008; Cheresky, 2006 y 199985). Del mismo modo, para Argentina en años recientes se observan cambios en las estrategias electorales; en la movilidad de los dirigentes, antes 'raramente se cruzaba la frontera interpartidaria'; y en los liderazgos, que desplazan a las organizaciones partidarias a la hora de configurar alianzas y la oferta electoral (Cheresky, 2012:39; Rodríguez, 2005; Malamud, 2005: 5). Específicamente sobre el peronismo, son

\footnotetext{
85 Aunque la bibliografía que aborda diversos contextos empíricos es abundante, aún está pendiente el estudio de las formas singulares en que estas transformaciones se produjeron en Salta.
} 
referidos cambios en su estructura y organización partidaria, el abandono de su concepción movimientista y la transformación en una organización especializada en la competencia electoral, entre otros (Levitsky, 2005; Ferrari, 2008).

Calvo y Escolar (2005: 2) destacan que existe una amplia literatura que muestra que los cambios profundos en un sistema político rara vez ocurren a nivel nacional de modo uniforme. Como vimos, muchas de estas transformaciones para las personas de ese universo, constituyeron elementos de una reconfiguración del mapa político local reciente. Si bien a partir de 1995 en Salta se hacen cada vez más frecuentes los liderazgos personalizados popularizados a través de un uso intensivo de los medios de comunicación y las movilidades interpartidarias, con la creación de nuevos partidos; se produce una paulatina pérdida de vínculos ideológicos del electorado y de identificación con los partidos -reflejado en la disminución drástica de la afiliación partidaria (del 25\% de toda la población en $2009^{86}$ ) y en la baja convocatoria partidaria-, el abandono de prácticas e identidad ideológica tradicionales peronistas y la redefinición de atributos y saberes necesarios para el reclutamiento partidario (Maidana, 2016). En los años observados vimos que los fenómenos referidos en el párrafo anterior que tienen como eje el debilitamiento de los partidos como forma de mediación social, son considerados novedosos.

Durante las elecciones de 2009 y 2011 dirigentes y cronistas verificaban que los liderazgos pasaban a ser más importantes que los partidos de los que formaban parte, sobre esto un dirigente, concejal y militante de los '80, colaborador de un semanario escribía en 2011: "Lo novedoso es que desaparecieron los partidos y la campaña es una guerra de caras y slogans, con un gran combustible por detrás que no son las ideas, sino el dinero"87 y llamaba la atención que las mediciones nacionales "cuantificaban a cada uno de los líderes de las opciones de manera personal sin importancia del partido que los contiene". 88 Las contradicciones entre las tradiciones ideológicas de los partidos, si bien aún podían ser significativas para algunos de ellos, ya no lo eran para los electores; la movilidad interpartidaria pasaba a ser la tónica de los momentos pre-electorales y, dada su masividad y recurrencia, se dificultaba el acompañamiento de las migraciones. El mapa político-partidario pre-2007 en el que el P.J. predominaba y confrontaba con segundas y terceras fuerzas de partidos tradicionales, había dejado de existir para dar lugar a una inestable, cambiante y compleja multiplicación de sectores, partidos y coaliciones creadas con fines electorales.

\footnotetext{
${ }^{86}$ Ver Redacción, 29 de setiembre de 2009, pág.3.

${ }^{87}$ Ver Redacción, 26 de marzo de 2011, pág.8.

88 Ver Nueva Propuesta, 14 de enero de 2011, columna de Jorge Villazón, pp. 4 y 5.
}

Para las personas de este universo, eran muchas las rupturas y diferencias con el período romerista anterior. Sin embargo, es posible considerar que una de las transformaciones locales que más impactaba era el abandono de la configuración política que se había mantenido desde la reapertura de la democracia, en la que el P.J. era el partido mayoritario predominante y el P.R.S. y la U.C.R. partidos opositores -débiles como alternativas electorales dadas las condiciones de competencia asimétricas-, para pasar a otra donde sus dirigentes se aliaban al líder del P.J. y desaparecía la oposición, o lo que se había conocido hasta entonces como tal. Por si fuera poco, sectores del P.J. pasaban a ser opositores y a reconfigurar ese espacio aliándose o conformando otras agrupaciones. No obstante, este nuevo mapa resultaba provisorio dado que las alianzas electorales podían activarse y desactivarse en cada elección (y sus fuerzas alternar el rol de opositor u oficialista), como en 2009 y 2011. Las nuevas expresiones mostraban que la política salteña perdía previsibilidad, certidumbre y fijeza.

Por otra parte, las divisiones intrapartidarias que se multiplicaban con velocidad, incluso daban cuenta de un cambio significativo en el peronismo local: el de su condición de fuerza monolítica mayoritaria. Si bien desde 1983 se habían reproducido históricos y dramáticos enfrentamientos internos y otros que respondían a circunstancias específicas y/o a la dinámica nacional, las divisiones y salidas de dirigentes para crear nuevos partidos habían sido reducidas y aisladas. Dada su última gran división en 2007 con la importante salida del romerismo, aunque se mantenía el predominio de la figura política del gobernador y de los dirigentes justicialistas éste pasaba a ser articulado con el sostén de alianzas y apoyos extrapartidarios. A propósito de esto, un analista, periodista radial y cronista titulaba su columna: "2010 fue el año en que murió el Panperonismo". 89

Foz do Iguaçu, 28 de octubre de 2018.

\section{Agradecimientos}

Este trabajo forma parte de mi tesis de doctorado, defendida ante el Programa de Pós-Graduação em Antropologia Social, de la Universidad de Brasília (Brasília, Brasil) en 2013, que aborda el proceso de sucesión y de reconfiguración del escenario político salteño en los años 2007 a 2011. Aquí presento una versión de uno de sus capítulos resumido y con modificaciones, sobre las cuales agradezco las sugerencias de Lia Zanotta Machado, realizada con apoyo de la Coordenação de Aperfeiçoamento de Pessoal de Nível Superior - Brasil (CAPES) - Código de Financiamento 001.

\footnotetext{
${ }^{89}$ Ver Nueva Propuesta, 14 de enero de 2011, columna de Jorge Villazón, pp. 4 y 5.
} 


\section{Referencias Bibliográficas}

Ardanaz, M., M. Lieras y M. Tommasi (2012). The Politics of Federalism in Argentina: Implications for Governance and Accountability", Inter-American Development Bank. Recuperado en: https://www.iadb.org/en

Balbi, F. A. (2007). De leales, desleales y traidores. Valor moral y concepción de política en el peronismo. Bs.As.: Antropofagia.

Balbi, F. A. (2010). Partido, Movimiento y conducción. Orientaciones cognitivas y prácticas políticas en el peronismo. Actas de la X Jornada de Historia Política, Mar del Plata, 2010, número 1. Edición en CD-ROM ISSN 1853- 5380.

Barth, F. (2000). O Guru, o Iniciador e Outras Variações Antropológicas (organização de Tomke Lask). Rio de Janeiro: Contra Capa Livraria.

Boltanski, L. y L. Thévenot (1991). De la justification: les économies de la grandeur. París: Galliard.

Borges, A. (2006). O emprego na política e suas implicações teóricas para uma antropologia da política. Anuário Antropológico. Rio de Janiero: Tempo Brasileiro, 9-125.

Calvo E. y M. Escolar (2008). La Nueva Política de Partidos en la Argentina: Crisis Política, Realineamientos Partidarios y Reforma Electoral. Recuperado en: http://gvptsites.umd.edu/ calvo/calvo-escolar-final-completo-Mayo-30.05.pdf

Cavarozzi, M. y Casullo, E. (2002). Los partidos políticos en Amé-rica Latina hoy: ¿consolidación o crisis? En M. Cavarozzi y J. M. Aba I Medina (h) (comps). El asedio de la política. Los partidos latinoamericanos en la era neoliberal. Rosario: Konrad Adenauer Stiftung-Homo Sapiens Ediciones, 9-30.

Cheresky, I. (1999). La ciudadanía, la opinión pública y los medios de comunicación: ciudadanía y política en la Argentina en los noventa, Revista de Ciencias Sociales, (10): 33-81.

Cheresky, I. (2006). La política después de los partidos, en Cheresky, I. (comp.) La política después de los partidos. Buenos Aires: Prometeo Libros.

Cheresky, I. (2012). Mutación democrática: otra ciudadanía, otras representaciones. En CHERESKY, I. (comp.) ¿Qué democracia en América Latina? Buenos Aires: Prometeo.

Dormagen, J. (2003). Le marché de l'emploi public de l'italie fasciste comme espace de mise en conformité politique. En J. Lagroye (ed.) La politisation. París: Belin, 403-424.

Frederic, S. y G. Soprano (2008). Panorama temático: antropología y política en la Argentina. Estudios de Antropología Social Vol. 1 (1). Centro de Antropología Social del Instituto de Desarrollo Económico y Social. Buenos Aires, 132-190.

Ferrari, M. (2008). El peronismo en la historia reciente. Algunas interpretaciones. Estudios de filosofía práctica e historia de las ideas. V. 10 (2): 63-83.

Gaxie, D. (2003). Une construction médiatique du spectacle politique? Réalité et limites de la contribution des médias au développement des perceptions négatives du politique. En Lagroye, Jacques La politisation. Paris: Belin, 325-356.

Latour, B. (2008). Reensamblar lo social. Una introducción a la teoría del actor-red. Bs. As.: Manantial.

Levitsky, S. (2005). La transformación del Justicialismo. Del Partido Sindical al Partido Clientelista. Buenos Aires: Iberoamericana.

Maidana, F. (2010). El ascenso y el descenso de los dirigentes del Partido Justicialista (P.J.) en los cargos gubernamentales, 1995-2005. Relaciones entre políticos y la política con J.C. Romero. Salta: Editorial de la Universidad Nacional de Salta

Maidana, F. (2013). La verosimilitud y el pragmatismo en los relatos de la prensa gráfica. Revista del Museo de Antropología 6 (1): 155-166.

Maidana, F. (2016). Los negros y los cholos. Sustitución de elites dirigenciales en el P.J. de Salta en los años 1995-2011. PolHis, Año 9 (17): 277-312.

Malamud, A. (2011). Las provincias como ancla. Le Monde Diplomatique, el Dipló 146, 4-5.

Manin, B. (1992). Metamorfosis de la Representación. En Dos Santos, Mario (coord.) Qué queda de la Representación Política. Caracas: CLACSO-Nueva Sociedad.

Novaro, M. (1994). Pilotos de tormentas: crisis de representación y personalización de la política en Argentina. 1989-1993. Buenos Aires: Letra Buena.

Pitkin, H. F. (2006). Representação: Palavras, Instituções e Idéias. Lua Nova, São Paulo, (67): 15-47.

Pousadela, I. M. (2004). ¿Crisis o metamorfosis? Aventuras y desventuras de la representación en la Argentina (1983-2003), en Documento de Trabajo de FLACSO Área Política, № 2: Veinte años de Democracia. Ensayos premiados, Buenos Aires, Setiembre.

Rodríguez, D. A. (2005). Nuevas formas políticas y cambios en el Peronismo, en VII Congreso Nacional de Ciencia Política Agendas Regionales en Conflicto. Recuperado de http://www. saap.org.ar/esp/docscongresos/congresossaap/VII/programa/ paneles/c/c3/rodriguez.pdf

Sidicaro, R. (2008). La pérdida de legitimidad de los partidos políticos argentinos, Revista Temas y Debates (16).

Simmel, G. (1927). La lucha. Sociología, Estudios sobre las formas de socialización. Revista de Occidente Vol. 1. Madrid.

Vandenverghe, F. (2006). Construction and criticism in the new french sociology, Sociedade e estado, vol. 21 (2): 313-366 